\title{
A Correlation Analysis of English Language Proficiency and Content-Area Cognitive Skills: A Gulf Region Perspective
}

\author{
Kate O'Neill and Peter Theuri \\ Zayed University
}

Learning and Teaching in Higher Education: Gulf Perspectives, Vol. 4, No. 1 (March 2007)

\begin{abstract}
Literature is replete with studies indicating the need to develop students' language skills; however, little research has emphasized the importance of language proficiency in enhancing learning or performance in specific content-area courses. This study investigates whether a student's English language proficiency can be associated with her performance in specific cognitive skills (knowledge, comprehension, application, and analysis) in an introductory accounting course. Data is summarized from students' performance on their first financial accounting examination as well as from students' academic history records as maintained by the university. A correlation analysis of the cognitive skills score with student language proficiency is used to identify initial relationships; and multiple regression analysis is subsequently used to identify interrelations between combined multiple dependent variables and the language proficiency variables. While the results show no association between TOEFL and overall performance, the mean of the English composition courses do show a significant association with knowledge and comprehension cognitive skills scores on the first financial accounting course. No associations are attached to the application and analysis cognitive skills. The results are meaningful to faculty in balancing language proficiency with quality instruction in content-area courses.
\end{abstract}

\section{Introduction and Reference Context}

English as a language of instruction has quickly taken precedence in most universities and colleges in the Arabian Gulf region. Ashcraft (2006) articulates it well when she writes that "Instructors in all disciplines ...... face the challenge of teaching the courses in their discipline in English to students who have learned (and who are continuing to learn) English as a Foreign Language (EFL)." Sonleitner \& Khelifa (2004) argue that content-area instructors are not only surprised by students' low level of English proficiency but at times may feel frustrated from having to teach content-area concepts as well as the English language. Often times, content-area courses have their own technical language that may compound the enormity of the demands placed on students to immediately comprehend and apply learned concepts. This study investigates whether there are any inherent associations between students' English language proficiency and their performance in specific cognitive skills as tested within the context of their first accounting course.

This study was conducted at Zayed University, a national university located in the United Arab Emirates, with an all-female Gulf Arab student body. With English considered a foreign language for all its students, the university requires all students to matriculate with a specified minimum level of English proficiency. The minimum score required to enroll in Colloquy (the first stage of the Zayed University Baccalaureate Program - equivalent to the General Education or Foundations programs of many North American universities) is $\mathbf{5 0 0}$ on the Institutional TOEFL paper-and-pencil test - or the equivalent using

O’Neill, K. and Theuri, P. (2007). A Correlation Analysis of English Language Proficiency and Content-Area Cognitive Skills: A Gulf Region Perspective. Learning and Teaching in Higher Education: Gulf Perspectives 4(1) . http://www.zu.ac.ae/Ithe/Ithe04_01_03_oneill.htm 
highest sub-test scores over a maximum three-year period. A 173 on the computer-based TOEFL (CBT) or a 5.0 on the International English Language Testing System (IELTS) is equally accepted.

The Test of English as a Foreign Language (TOEFL), a product of the Educational Testing Service of Princeton, New Jersey, USA, "measures the ability of nonnative speakers of English to use and understand English as it is spoken, written, and heard in college and university settings" (Educational Testing Service, 2006). Currently, more than 6,000 licensing agencies, colleges and universities use the TOEFL. Students at Zayed University most often undertake the Institutional TOEFL Program (ITP) version of the exam. The ITP is a multiple choice test, primarily receptive in nature, derived from questions previously used on the full form TOEFL. The ITP consists of three equally weighted sections. Each section has a standard number of questions and a time limit: Listening Comprehension, 50 questions in 35 minutes; Structure and Written Expression, 40 questions in 25 minutes; and Reading Comprehension, 50 questions in 55 minutes. Listening comprehension is defined as the ability to understand spoken North American English. In the Structure and Written Expression section of the examination "the ability to recognize language that is appropriate for standard written English" is assessed while the Reading Comprehension section measures the student's ability to understand short university-level texts (Educational Testing Service, 2006).

Students who do not demonstrate the minimum required level of English language proficiency to enter the Colloquy Program are placed in courses offered by the Readiness Program. The Readiness Program (the name of the Zayed University pre-Baccalaureate academic preparation program from 20012006, changed to the Academic Bridge Program from fall 2006) helps students to increase their English proficiency through academic English courses. These courses are based on an integrated skills curriculum and are offered by the Zayed University English Language Center. Because of the varied proficiencies that students come with, each student has a different tenure in the Readiness program.

The initial TOEFL/ITP testing date varies from student to student. The initial time of testing ranges from the final year of secondary study to as late as the end of the first academic year of study in the Readiness Program. Most students sit the exam for the first time 6 to 20 weeks after entry into the Readiness Program. Students who fail to achieve the minimum required score after the initial attempt are able to sit alternate versions of the test at least every 10 weeks until they achieve the required score or its equivalent.

Once students attain the minimum required level of language proficiency and a mark of 'satisfactory' for each of the Readiness courses in which they were enrolled, they are permitted entry to the Colloquy Program. The Colloquy Program is centered on a Liberal Arts' based core curriculum that introduces students to the social and physical sciences, mathematics, and literature, rhetoric and composition. A primary feature of the Colloquy Program is the three-course English composition sequence. All students are required to enroll in these three courses. A guiding tenet of the Colloquy composition course sequence is

Academic success in a student's major is dependent on her ability to read, write and speak academic English. The Colloquy facilitates the systematic improvement of this skill. During each of the Colloquy's first three semesters, students enroll in an English Composition course (COL 140, 145, 240). Each of these courses is designed to develop her skills in using the language as a tool for critical analysis and self-expression...In order to facilitate systematic improvement, students work is assessed using standardized rubrics. This method assures that all students are required to meet common standards (Zayed University, 2007).

It is within this context that Zayed University offers a unique opportunity in which to investigate how language proficiency impacts students' performance in content-area courses. This context is

O’Neill, K. and Theuri, P. (2007). A Correlation Analysis of English Language Proficiency and Content-Area Cognitive Skills: A Gulf Region Perspective. Learning and Teaching in Higher Education: Gulf Perspectives 4(1) . http://www.zu.ac.ae/Ithe/Ithe04_01_03_oneill.htm 
enriched by the fact that Zayed University not only is heavily staffed by Western/Western-educated faculty but also prescribes that its educational programs be in line with the American education style almost exclusively undertaken in the English language.

A deeper understanding of any association between students' language proficiency and their performance on content-area based cognitive skills would be very beneficial to both content-area faculty and English language faculty. Content-area faculty can be made conscious of the need to moderate specific content-area vocabulary with student language proficiencies in order to maximize learning. Some researchers emphasize the goal is not to simplify the concepts taught in content-areas but rather to simplify the language level used to convey the concepts taught (Echevarria, Vogt and Short, 2004). With this consciousness, content-area faculty will not teach content-based concepts in isolation of language skills. English language faculty, on the other hand, although already cognizant of the need to assist students with the development of language proficiency, can benefit from the findings of studies such as this as they serve to underscore the importance of providing students with strategies to assimilate the new language/vocabulary they will encounter in content-area courses. Such concerted efforts will enhance the quality of instruction and most importantly the quality of student learning.

\section{Literature Review}

\section{The Learning Process}

The most commonly accepted theory of learning, Bloom's taxonomy (Bloom, 1956), views learning as a progressive process. As this study is conducted within an accounting context, Bloom's theory is discussed within such an environment. Simple facts are first memorized and then sufficient detail to be able to explain those facts is added on. The first two levels (knowledge and comprehension) rely almost entirely on memory and are sometimes referred to together as declarative knowledge (Anderson, 1983; Jonassen, Beissner, \& Yacci, 1993) - that is, they involve knowing what something is, but exclude the ability to use that knowledge. Knowledge requires only the bringing to mind of appropriate information, and is considered the lowest level of learning outcome in the cognitive domain. Comprehension, on the other hand, can be demonstrated by the ability to grasp the meaning of concepts beyond simply remembering them. Comprehension represents the lowest level of understanding. Within the financial accounting framework, being able to identify a transaction as either a deferral or an accrual is a good demonstration of mastery at this level. The third level, application, refers to the ability to use learned material in concrete situations. In accounting, this may include the application of accounting rules (principles); computing depreciation expense would be an example of this third level. The fourth level, analysis, involves the ability to break down material into its component parts so that its organizational structure may be understood. Analyzing transactions and preparing journal entries falls in this level of learning outcome. The other two higher learning outcomes of synthesis and evaluation are so scarcely tested in introductory accounting courses that they are not included in this study.

\section{Communication Needs of Business Students}

The importance of strong communication skills to today's and tomorrow's business professionals is undoubtedly clear. The Association to Advance Collegiate Schools of Business (AACSB), the premiere accrediting body of undergraduate and graduate business programs, in its list of Learning Standards at the Undergraduate level lists communication skills first (2003). Similarly, International Education Guideline (IEG) 9, published by the International Federation of Accountants (IFAC), stipulates communication skills as one of three essential skill areas that students need to develop. This is further

O’Neill, K. and Theuri, P. (2007). A Correlation Analysis of English Language Proficiency and Content-Area Cognitive Skills: A Gulf Region Perspective. Learning and Teaching in Higher Education: Gulf Perspectives 4(1) . http://www.zu.ac.ae/Ithe/Ithe04_01_03_oneill.htm 
defined as the ability to "present, discuss, and defend views effectively through formal and informal, written and spoken, language" (IFAC, 1996). Advanced language skills are requisite for success in accounting courses and the profession. It is clear from the emphasis given by these bodies, that there are quality benefits accruing to programs that strengthen students' communication and language skills.

\section{TOEFL}

The literature is scant with regard to current studies investigating the relationship between the language proficiency of non-native users of English and academic success in English-medium tertiarylevel undergraduate content-area courses outside of North America. A few studies have looked at the relationship between the language proficiency of non-native users of English and academic success in graduate programs in North America (Bayliss and Raymond 2004), most particularly the United States (Alderman, 1982; Hicks and Richardson, 1984; Light, Xu \& Mossop, 1987; Krausz et al. 2005).

Exemplary of the concerns relating to the language proficiency of non-native users of English and academic success in English-medium content-area courses are those expressed by Krausz et al. (2005) with regard to the TOEFL and accounting. First, the TOEFL tests general English not business-specific language or the jargon of the specialization. Second, in introductory and lower level accounting courses, quantitative skills predominate in the curriculum. This second concern is supported by a previous study conducted by Ayers and Quattlebaum (1992) with engineering students. This is not to say the TOEFL is irrelevant to all business, and specifically accounting, courses: "It is possible that TOEFL scores would be a positive factor, however, in upper level accounting or auditing courses, particularly if those courses use a case method of instruction and/or require written research assignments. Another possibility is that the higher communication skills associated with higher TOEFL scores might improve performance in introductory graduate accounting study, but that such improvement was not captured by the metric used to measure student performance in this case" (Krausz et al., 2005, p.109).

Results from work on the relationship between TOEFL and academic performance are contradictory. Wilson (1985), in ETS Research Report No. 85-17, reported a relationship between TOEFL score and academic performance in graduate-level business courses. In later research also sponsored by ETS, Wilson (1986) found a student's TOEFL score to be a reliable predictor of academic success only in the biosciences and social sciences. An independent study by Krausz et al. (2005) showed no relationship between TOEFL score and academic performance for international students in 11 MBA programs located in the Northeast region of the United States. These findings bolster those of Light, Xu \& Mossop (1987) which found (across a span of academic subject areas) that TOEFL is not an effective predictor of grade point average for non-native English speaking international graduate students. Hoeffer and Gould (2000) also found no correlation between TOEFL scores and grade point average at the graduate level.

Studies conducted by Dulay, Burt and Krashen (1982) and Graham (1987) question the usefulness of TOEFL in predicting students' productive proficiency in English. Duran et al. (1985) identified the receptive nature of the test as a limitation in this regard. The situation is further complicated by the difficulty of defining language proficiency (Canale, 1983). However, an investigation by Mpofu et al. (1998) into problem-based learning conducted with Emirati medical students at the United Arab Emirates University showed the TOEFL to be the best predictor of students' oral contributions.

As with the relationship between TOEFL and academic success, the relationship between second language proficiency and academic performance is not conclusive. Some studies report no link between second language proficiency and academic performance (Hwang \& Dizney, 1970; Mulligan, 1966; Shay, 1975; Sugimoto, 1966 - all reported in Bayliss \& Raymond, 2004), while Dunnett (1985) demonstrated the importance of a minimum level of English language proficiency in order for non-native English

O'Neill, K. and Theuri, P. (2007). A Correlation Analysis of English Language Proficiency and Content-Area Cognitive Skills: A Gulf Region Perspective. Learning and Teaching in Higher Education: Gulf Perspectives 4(1) . http://www.zu.ac.ae/Ithe/Ithe04_01_03_oneill.htm 
speaking international students to be academically successful in U.S. tertiary programs. Others reported low but significant correlations (Gue \& Holdaway, 1973; Light, Xu, \& Mossop, 1987). These mixed results may be a function of the complexity of capturing and assessing the range of language skills needed for academic success (Cummins, 1983). Taking into account Cummins' Cognitive Academic Language Proficiency (CALP) construct (Cummins, 2003), questions arise regarding TOEFL as a useful measure of proficiency in the tertiary academic context.

Because of these mixed findings, continued research that investigates meaningful associations of English language proficiency with subsequent student success is important if such relationships are to be fully understood.

\section{Research Questions}

The primary question investigated in this study is whether there is any association between students' English language proficiency and their performance in cognitive skill scores in an introductory content-area course. Cognitive skills scores are categorized based on Bloom's Taxonomy and are derived from scores on the first examination in an introductory financial accounting course.

\section{Sample and Data Collection}

In this study, associations between student language proficiency and student performance on content-area based cognitive skills are investigated at an all-female Arab university (Zayed University) located in the Gulf region of the Middle East. Data is based on student performance on specific cognitive skills-based questions on an introductory accounting course examination. Two sections of the same course taught by the same instructor are used to supply the needed data. It is important that the sample consist of the sections taught by the same instructor in order to minimize the introduction of other factors stemming from varied instructional methods. Fifty-six students comprise the sample size. Data points for each student (TOEFL scores and entry proficiency level, grade obtained in the Zayed University three English-composition course sequence, and overall tenure at the university) are obtained directly from students' academic history records as maintained by the university.

Students' English language proficiency is determined in two ways. First, we use a student's score from TOEFL - an externally-validated standardized assessment instrument that defines language proficiency in terms of reading, listening, and structure/written expression. Then, we use the student's mean grade point (hereafter referred to as AvEng) from the three-course Zayed University English composition sequence.

The four levels of cognitive skills are based on students' performance on their first examination in the introductory financial accounting course. The questions were patterned based on the detailed definitions of each cognitive skill as described by Bloom, B. (Ed.). (1956). Other researchers (Anderson, 1983; Jonassen, Beissner, \& Yacci, 1993) provide extensive descriptions of each of the cognitive skills. A composite of these descriptions forms the basis for drafting the questions on the accounting examination used to assess students performance. A minimum of two questions (with several subsets to the questions) per cognitive skill were included in the examination. Depending on the cognitive skill, a variation of question formats was used including multiple-choice, problem solving, and analysis type. The average of the scores for each cognitive skill was used for further analysis.

We use correlation analysis to evaluate for any initial prima facie relationships between language proficiency and student performance on various cognitive skills. Correlation analysis is a statistical tool

O'Neill, K. and Theuri, P. (2007). A Correlation Analysis of English Language Proficiency and Content-Area Cognitive Skills: A Gulf Region Perspective. Learning and Teaching in Higher Education: Gulf Perspectives 4(1) . http://www.zu.ac.ae/Ithe/Ithe04_01_03_oneill.htm 
widely used for assessing the strength and nature (direction) of observed relationships/associations between two or more variables of interest. The degree to which a systematic covariation between two variables may exist is a descriptive statistic reported as the correlation coefficient $(r)$. The correlation coefficient is stated in numeric form between positive one and negative one. A perfect positive relationship (as one variable increases, so does the other) is therefore presented as +1 , whereas a perfect negative relationship (as one variable increases, the other decreases) is presented as -1 . A correlation coefficient is a measure of linear association. An important point to keep in mind is that two variables can be perfectly related, but if the relationship is not linear, the correlation coefficient is not an appropriate statistic for measuring their association. We subsequently use the linear regression technique to model the value of the dependent variable based on its linear relationship to each of our covariates. The model assumes that there is a linear, or "straight line," relationship between the dependent variable and each predictor variable. This relationship is described in the following model:

Cognitive Skill $=$ Intercept $+\beta$ (Language Proficiency $)+\beta$ (Tenure $)$

In addition to the five separate univariate comparisons, we then run a multivariate regression analysis with the model that includes: Knowledge (know), Comprehension (compr); Application (appli); Analysis (analy) as the multiple dependent variables and Language Proficiency and Tenure as the covariates, as well as an interaction term between Language Proficiency and Tenure. Tenure is included in the model as a control variable because it seems plausible that the longer a student has been at the university that fosters English language as the medium for instruction, the more proficient the language skills. We therefore control for students' tenure as measured by how many terms the student has spent at Zayed University (including those spent in the English Language program).

\section{Results}

Pearson correlations for the variables along with the data sample size in each cell are presented in Table 1 below. AvEng is significantly and positively correlated with each of the cognitive skills as tested on the first accounting examination. TOEFL scores show a significantly positive correlation with analytical skills in the first examination. However, the TOEFL scores are not significantly correlated with the other cognitive skills tested on the first accounting examination. It is interesting to note that TOEFL scores are significantly correlated with AvEng and Tenure but are not significantly correlated with the results of the other three cognitive skills (comprehension, application, and analysis) tested on the first accounting examination. 
Table 1: Pearson Correlations of Test Variables and Cognitive Skills

\begin{tabular}{|l|l|l|l|l|l|l|l|l|}
\hline & & Know & Comp & Appl & Analy & Total & Tenure & AVEng \\
\hline \multirow{5}{*}{ Tenure } & Correlation & & & & & & & \\
& Coefficient & -0.194 & 0.047 & -0.063 & -0.261 & -0.192 & & \\
& Significance & 0.16 & 0.736 & 0.65 & 0.056 & 0.164 & & \\
\cline { 2 - 9 } AVEng & $\mathrm{N}$ & 54 & 54 & 54 & 54 & 54 & & \\
\cline { 2 - 9 } & Correlation & & & & & & & \\
& Coefficient & $.516\left(^{* *}\right)$ & $.516\left(^{* *}\right)$ & $.530\left(^{* *}\right)$ & $.405\left(^{*}\right)$ & $.548\left(^{*}\right)$ & $.402\left(^{*}\right)$ & \\
& Significance & 0.000 & 0.000 & 0.000 & 0.002 & 0.000 & 0.003 & \\
& $\mathrm{~N}$ & 56 & 56 & 56 & 56 & 56 & 54 & \\
\cline { 2 - 9 } & Correlation & & & & & & & \\
& Coefficient & 0.135 & -0.057 & 0.079 & $.320\left(^{*}\right)$ & 0.216 & $.735\left(^{* *}\right)$ & $.394\left(^{* *}\right)$ \\
& Significance & 0.326 & 0.68 & 0.565 & 0.017 & 0.114 & 0 & 0.003 \\
& $\mathrm{~N}$ & 55 & 55 & 55 & 55 & 55 & 54 & 55 \\
\hline
\end{tabular}

While AvEng shows significant correlations with all the dependent variables, these correlations do not clearly point to the direction of the relationship that may exist between TOEFL and the dependent variables. Since AvEng scores are significantly associated with the dependent variables, and TOEFL scores are significantly associated with AvEng, these results do not identify what the relationship, if any, is between TOEFL and the dependent variables. In order to understand any relationships that may exist within these variables, five additional univariate regressions are conducted that include both the AvEng and total TOEFL score as the independent variables while still controlling for students' tenure. It is important to control for students' tenure since the longer the student has been in an English speaking environment the easier it is for her to improve language skills. Students at Zayed University enter at various levels of English readiness and so the length of their preparation to begin university level curriculum varies. In none of the regressions did the TOEFL score contribute significantly to the covariance in the cognitive skill. AvEng, on the other hand, was statistically significant in each of the regressions. Given that univariate tests do not simultaneously consider interdependencies that may exist among various dependent variables, we conducted a multivariate regression - General Linear Model (GLM) with TOEFL scores, AvEng, and Tenure as independent variables and the four cognitive skills (knowledge, comprehension, application, and analysis) as the multiple dependent variables. Wilks' Lambda (explaining the contribution of each variable to the overall model) showed that TOEFL scores did not contribute significantly to the model and that only AvEng contributed significantly ( $F=2.582, p=.024)$ to the model. Recognizing that multi-colinearity could exist in a model where both AvEng and TOEFL scores are included, another model was specified excluding AvEng. Our findings do not differ from those of other researchers who have found no relationship between TOEFL scores and students' performance at various learning levels (Krausz, et. al 2005; Wilson, 1986). The collective results suggest that AvEng is consistently a dominant variable in explaining the relationship between student language skills and their performance on specific cognitive skill as tested on their first accounting examination. No further analysis is warranted where TOEFL scores are considered.

O’Neill, K. and Theuri, P. (2007). A Correlation Analysis of English Language Proficiency and Content-Area Cognitive Skills: A Gulf Region Perspective. Learning and Teaching in Higher Education: Gulf Perspectives 4(1) . http://www.zu.ac.ae/Ithe/Ithe04_01_03_oneill.htm 
The question of interest is whether the specific cognitive skills tested in the first accounting examination are significantly associated with AvEng (language skills) while considering a non-English speaking students' tenure in an English learning environment. Both univariate linear regressions and multivariate regression tests were conducted. An advantage of the univariate regressions is that measurement errors in predictor (independent) variables do not affect the relationship inherent between the dependent variable and other independent variables. In addition, regression results offer an advantage of showing the covariance explained by the relationships through the R-squared statistic. Results of each of the univariate regressions are presented in Table 2(a) through 2(e) (see appendix). Below is a discussion of the results for each cognitive skill (dependent variable).

The correlation between the students' language skills and the knowledge cognitive skill results is statistically significant $(t=2.416, p<.05)$. The variance explained ( $R$-Squared) by the association is $14 \%$ (the remaining $86 \%$ variance is from sources unexplained by this model). The correlation of students' language skills and comprehension scores is statistically significant $(t=3.673 ; p<0.01)$. The model's $\mathrm{R}$ Squared is $21 \%$. Language skills scores are significantly associated with application cognitive skills $(t=$ 3.129; $p<0.05$ ) with $16 \%$ of the covariance explained by the relationship. The univariate model for the analysis cognitive skill shows that no significant association exists between students' language skills and their performance on analytical portions of their first accounting examination ( $t=1.208 ; p=0.232$ ). Ignoring the individual cognitive skills categorization, the students' language skills show a significant association with the total score on the first examination ( $t=2.868 ; p<0.01$ ) with $17 \%$ of the covariance explained.

In addition to the five univariate regressions discussed above, we run a general linear multivariate model in order to relate students' language skills with performance on cognitive skills based on the first accounting examination. The GLM multivariate test offers the advantage that the relationship between multiple dependent and independent variables can be simultaneously modeled while controlling for other independent variables. The results as presented in Table 3(a) show significant values for the Wilks' Lambda statistic that seeks to show whether the related variable contributes significantly to the overall model. This statistic allows the researcher to proceed with further analysis of between-subjects effects for each independent variable. Table 3(b) shows the more detailed results of the association of the independent variables and each of the dependent variables. The statistics for the corrected model shows that only two of the four models (knowledge and comprehension) are significant enough for interpretation. Overall models for application and analysis are not statistically significant.

While controlling for students' tenure at the university, language skills are significantly associated with knowledge cognitive skills ( $F=2.994 ; p<0.05)$ and comprehension cognitive skills $(F=9.222 ; p<0.01)$. There is no apparent association between language skills and either application nor analytical cognitive skills as measured in this study.

\section{Discussion}

While this study was not intended to test and explain all the variables that would predict success in a content-area course, the study establishes whether these students' language proficiency as measured by the TOEFL and by students' composition grades has any association with their performance in content-area cognitive skills. Cognitive skills in this study are determined from students' first financial accounting examination. The results suggest that TOEFL scores as a measure of English language proficiency are not associated with students' performance in content-area cognitive skills. Several factors can possibly explain this finding. First, TOEFL scores do not reflect the use of any specific content-area vocabulary as would be expected in a financial accounting course. Thus the score may not represent

O'Neill, K. and Theuri, P. (2007). A Correlation Analysis of English Language Proficiency and Content-Area Cognitive Skills: A Gulf Region Perspective. Learning and Teaching in Higher Education: Gulf Perspectives 4(1) . http://www.zu.ac.ae/Ithe/Ithe04_01_03_oneill.htm 
proficiency worth associating with performance in accounting-based cognitive skills. Secondly, TOEFL scores are not intended to measure other proficiencies such as quantitative based skills required in a financial accounting course. Similar findings were reported by Krausz et al. (2005) and Ayers and Quattlebaum (1992). A similar study may be worth conducting with other qualitative courses like Auditing or courses that use case studies more regularly than the introductory financial accounting course. Case-based courses involve a lot more reading and extraction of non-quantitative information from written cases, and analysis than do quantitative courses. In addition, it may be a worthwhile effort to investigate what impact using the final examination or the final course grade would have on the correlation results.

On the other hand, the average grades of the English composition three-course sequence show very strong association with students' performance in content-area cognitive skills. The first two English composition courses of the three-course sequence are usually taken by students in the terms immediately prior to their enrollment in the first financial accounting course, while the third composition course is taken concurrently with accounting. This close correlation with the accounting course may suggest that the preparation they would have just completed can be more readily associated with their performance in subsequent courses. Undoubtedly, the English composition courses do enhance their language proficiency and may even improve their comprehension and knowledge skills. The results suggest that language proficiency cannot be associated with performance in both the application and analytical cognitive skills as measured in the first accounting examination. Comprehension cognitive skills involve grasping the meaning of concepts and terms while knowledge skills involve the ability to recognize items. These two cognitive skills are on the lowest end of Bloom's taxonomy of learning outcomes. What is clear is that acquisition of appropriate levels of English language proficiency may be more useful in meeting the comprehension and knowledge levels of cognitive skills in content-area courses. This finding suggests that instructors in content-area courses, like introductory financial accounting course, may spend less effort in comprehension and knowledge level cognitive skills in a content-area course since students enrolling in such content-area courses may bring with them the relevant English proficiency.

Another important implication drawn from the associations found in this study is that the English composition faculty should consciously have the added goal of training students to succeed in subsequent content-area introductory courses, at least from a language proficiency aspect of comprehension and knowledge cognitive skills. Although no quantifiable data has been collected regarding the effectiveness of specific strategies with introductory accounting students at Zayed University, the researchers have found anecdotal evidence in the form of improved examination scores in introductory MIS and business communications courses of the success of teaching students vocabulary learning strategies such as roots, prefixes, and suffixes, and academic reading strategies including SQ3R, contextual reading, and the use of dual entry reading journals. Vocabulary learning strategies provide students with a means to deal with new or unfamiliar words without the delay or interruption caused by using dictionaries (in particular, Arabic-English dictionaries). Academic reading strategies provide students with methods to assimilate content (in both the first and the second language).

Even with the limitations that may be associated with this study such as in the specific use of an accounting examination to capture cognitive skills levels, or inadequacies that may exist in capturing English language proficiency, the potential benefits of the results clearly outweigh such limitations. If these results yield a concerted effort between English language faculty and content-area faculty in minimizing language-based learning barriers for students whose English is considered a foreign language, then the university goal of producing quality graduates will be enhanced.

O’Neill, K. and Theuri, P. (2007). A Correlation Analysis of English Language Proficiency and Content-Area Cognitive Skills: A Gulf Region Perspective. Learning and Teaching in Higher Education: Gulf Perspectives 4(1) . http://www.zu.ac.ae/Ithe/Ithe04_01_03_oneill.htm 


\section{References}

AACSB International (2003). Eligibility procedures and standards for business accreditation. Retrieved 12 December 2006 from http://www.aacsb.edu/accreditation/brc/standards-4-25.pdf

Alderman, D. L. (1982). Language proficiency as a moderator variable in testing academic proficiency. Journal of Educational Psychology , 74 (4), pp.580-587.

Anderson, J. (1983). The architecture of cognition. Cambridge, MA: Harvard University Press.

Ashcraft, N. (2006). Overcoming language barriers in content-area instruction. Learning and Teaching in Higher Education: Gulf Perspectives, 3(1).

Ayers, J. and Quattlebaum, R. (1992). TOEFL performance and success in masters program in engineering, Education and Psychological Measurement, 52(6), pp. 973-975.

Bayliss, D. \& Raymond, P. (2004). The link between academic success and L2 proficiency in the context of two professional programs. The Canadian Modern Language Review/La Revue Canadienne des Langues Vivantes, 61(1) (September/septembre), 29-51.

Bloom, B. (Ed.). (1956). Taxonomy of educational objectives: The classification of educational goals: Handbook I, cognitive domain. New York, Toronto: Longmans, Green.

Canale, M. (1983). From communicative competence to communicative language pedagogy. In J. Richards \& R. Schmidt (Eds.), Language and Communication (pp.2-27). New York: Longman.

Cummins, J. (1983). Language proficiency and academic achievement. In J. Oller (Ed.), Issues in language testing research (pp.108-129). Rowley, MA: Newbury House.

Cummins, J. (2003). BICS and CALP. Retrieved 01 December 2006 from http://www.iteachilearn.com/cummins/bicscalp.html

Dulay, H., Burt, M, \& Krashen, S. (1982). Language two. Oxford University Press, New York.

Dunnett, S. (1985). Current communicative needs of foreign students in the college/university classroom. International Programs Quarterly, 1 (2), 22-26.

Duran, R., Canale, M., Penfield, J., Stanfield, C., \& Liskin-Gasparro, J. (1985). TOEFL from a communicative viewpoint on language proficiency (Research Report No. 17). Princeton, NJ: Educational Testing Service.

Echevarria, J., Vogt, M., \& Short, D.J. (2004). Making content comprehensible for English learners: The SIOP model ( $2^{\text {nd }}$ ed.). New York: Pearson Education.

Educational Testing Service (2006). TOEFL - test of English as a foreign language. Retrieved 15 December 2006 from http://www.ets.org/portal

Graham, J.C. (1987) English language proficiency and the predication of academic success. TESOL Quarterly, 21, 505-21.

Gue, L. and Holdaway, E. (1973). English proficiency tests as predictors of success in graduate studies in education. Language Learning, 23, 89-103.

Hicks, D., and Richardson, F. (1984). Predicting early success in intermediate accounting: the influence of entry examination and GPA. Issues in Accounting Education 1984 (American Accounting Association, 1984), pp.61-67.

O’Neill, K. and Theuri, P. (2007). A Correlation Analysis of English Language Proficiency and Content-Area Cognitive Skills: A Gulf Region Perspective. Learning and Teaching in Higher Education: Gulf Perspectives 4(1) . http://www.zu.ac.ae/Ithe/Ithe04_01_03_oneill.htm 
Hoeffer, P. and Gould, J. (2000) Assessment of admission criteria for predicting students' academic performance in graduate business programs, Journal of Education for Business, 75(4), pp. 225229.

International Federation of Accountants (IFA) (1996) International education guideline 9: prequalification education, assessment of professional competence and experience requirements of professional accountants. Retrieved 18 December 2006 from http://www.ifac.org/Members/HTML Files/Education/IEG09/IEG9.tmpl

Jonassen, D., Beissner, K., \& Yacci, M. (1993). Structural knowledge techniques for representing, conveying, and acquiring structural knowledge. Hillsdale, NJ: Lawrence Erlbaum Associates, Publishers Hove \& London.

Krausz, J., A. Schiff, J. Schiff, and J. Van Hise. (2005). The impact of TOEFL scores on placement and performance of international students in the initial graduate accounting class. Accounting Education: an international journal, 14(1), pp. 103-111.

Light, R., Xu, M. and Mossop, J. (1987) English proficiency and academic performance of international students. TESOL Quarterly, 21, 251-261.

Mpofu, D., Lanphear, .J, Stewart, T., Das, M., Ridding, P. \& Dunn, E. (1998). Facility with the English language and problem-based learning group interaction: findings from an Arabic setting. Medical Education, 32, 479-485.

Sonleitner, N. and Khelifa, M. (2004). Western-Educated Faculty Challenges in a Gulf Classroom. Learning and Teaching in Higher Education: Gulf Perspectives, 2(1), 1-21.

Wilson, K. (1985). Factors affecting GMA predictive validity for foreign MBA students: an exploratory study, ETS Research Report No. 17. Princeton, NJ: Educational Testing Service.

Wilson, K. (1986). The relationship of GRE general test scores to first-year grades for foreign graduate students: Report of a cooperative study (Research Report No. 44). Princeton, NJ: Educational Testing Service.

Zayed University (2007). Retrieved 09 January 2007 from http://www.zu.ac.ae/catalog/documents/cat2006 11.pdf

\section{Authors}

Kate $\mathbf{O}^{\prime}$ Neill is an instructor of business communications at Zayed University. She was the director of training and development for an international jewelry firm. She has taught in Japan, Argentina, Jamaica, the United States, and the Republic of Kiribati..

Peter Theuri is a visiting associate professor of accounting at Zayed University. He received his doctorate in accounting from Mississippi State University (USA) and is a certified public accountant (USA). He has taught accounting at various universities for the past eighteen years. Dr. Theuri is on sabbatical leave from Northern Kentucky University during this academic year.

\section{Appendix: Tables 2(a)-3(b)}

Table 2(a) Linear Regression Model Summary of Knowledge and English Proficiency (AvEng)

O’Neill, K. and Theuri, P. (2007). A Correlation Analysis of English Language Proficiency and Content-Area Cognitive Skills: A Gulf Region Perspective. Learning and Teaching in Higher Education: Gulf Perspectives 4(1) . http://www.zu.ac.ae/Ithe/Ithe04_01_03_oneill.htm 


\begin{tabular}{|l|l|l|l|l|} 
Model & $\mathrm{R}$ & R Square & $\begin{array}{l}\text { Adjusted R } \\
\text { Square }\end{array}$ & $\begin{array}{l}\text { Std. Error of the } \\
\text { Estimate }\end{array}$ \\
\hline 1 & $.369(\mathrm{a})$ & 0.136 & 0.103 & 14.5006 \\
\hline
\end{tabular}

a. Predictors: (Constant), Tenure, AVEng

Coefficients(a)

\begin{tabular}{|c|c|c|c|c|c|c|}
\hline & \multirow[b]{2}{*}{$\begin{array}{l}\text { Standardized } \\
\text { Coefficients }\end{array}$} & \multirow[b]{3}{*}{$\mathrm{t}$} & \multirow[b]{3}{*}{ Sig. } \\
\hline & & \multicolumn{2}{|c|}{ Unstandardized Coefficients } & & & \\
\hline \multicolumn{2}{|c|}{ Model } & B & Std. Error & Beta & & \\
\hline \multirow[t]{3}{*}{1} & (Constant) & 63.749 & 8.868 & & 7.189 & 0.000 \\
\hline & AVEng & 6.262 & 2.591 & 0.343 & 2.416 & 0.019 \\
\hline & Tenure & 0.328 & 0.834 & 0.056 & 0.393 & 0.696 \\
\hline
\end{tabular}

a. Dependent Variable: Knowledge

Table 2(b): Linear Regression Model Summary of Comprehension and English Proficiency (AvEng)

\begin{tabular}{|l|l|l|l|l|}
\hline Model & $R$ & R Square & $\begin{array}{l}\text { Adjusted } \\
\text { Square }\end{array}$ & $\begin{array}{l}\text { Std. Error of the } \\
\text { Estimate }\end{array}$ \\
\hline 1 & $.459(\mathrm{a})$ & 0.211 & 0.180 & 16.776 \\
\hline
\end{tabular}

a. Predictors: (Constant), Tenure, AVEng

Coefficients(a)

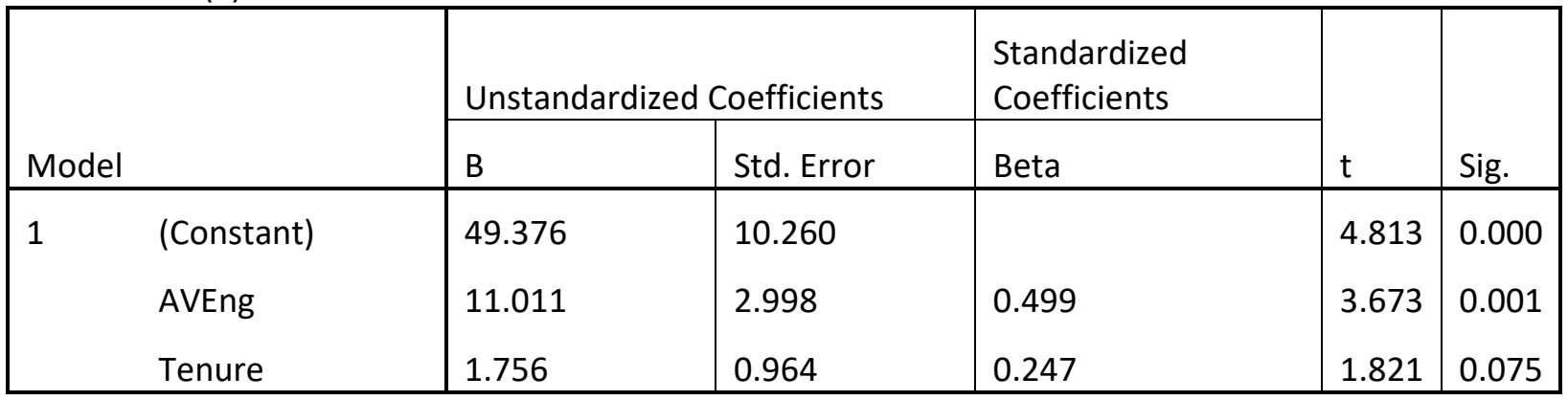

a. Dependent Variable: Comprehension

Table 2(c): Linear Regression Model Summary of Application and English Proficiency (AvEng)

\begin{tabular}{|l|l|l|l|l|}
\hline Model & $\mathrm{R}$ & R Square & $\begin{array}{l}\text { Adjusted } \\
\text { Square }\end{array}$ & $\begin{array}{l}\text { Std. Error of the } \\
\text { Estimate }\end{array}$ \\
\hline
\end{tabular}

O'Neill, K. and Theuri, P. (2007). A Correlation Analysis of English Language Proficiency and Content-Area Cognitive Skills: A Gulf Region Perspective. Learning and Teaching in Higher Education: Gulf Perspectives 4(1) . http://www.zu.ac.ae/Ithe/Ithe04_01_03_oneill.htm 


\begin{tabular}{|l|l|l|l|l|}
1 & $.354(\mathrm{a})$ & 0.125 & 0.091 & 28.853 \\
\hline
\end{tabular}

a. Predictors: (Constant), Tenure, AVEng

Coefficients(a)

\begin{tabular}{|c|c|c|c|c|c|c|}
\hline \multirow{2}{*}{\multicolumn{2}{|c|}{ Model }} & \multicolumn{2}{|c|}{ Unstandardized Coefficients } & \multirow{2}{*}{$\begin{array}{l}\text { Standardized } \\
\text { Coefficients } \\
\text { Beta } \\
\end{array}$} & \multirow[b]{2}{*}{$\mathrm{t}$} & \multirow[b]{2}{*}{ Sig. } \\
\hline & & B & Std. Error & & & \\
\hline \multirow[t]{3}{*}{1} & (Constant) & 28.482 & 17.646 & & 1.614 & 0.113 \\
\hline & AVEng & 13.892 & 5.156 & 0.385 & 2.694 & 0.010 \\
\hline & Tenure & 1.534 & 1.659 & 0.132 & 0.925 & 0.359 \\
\hline
\end{tabular}

a. Dependent Variable: Application

Table 2(d): Linear Regression Model Summary of Analysis and English Proficiency (AvEng)

\begin{tabular}{|l|l|l|l|l|}
\hline Model & $R$ & R Square & $\begin{array}{l}\text { Adjusted R } \\
\text { Square }\end{array}$ & $\begin{array}{l}\text { Std. Error of the } \\
\text { Estimate }\end{array}$ \\
\hline 1 & $.307(\mathrm{a})$ & 0.094 & 0.059 & 14.054553192240400 \\
\hline
\end{tabular}

a. Predictors: (Constant), Tenure, AVEng

Coefficients(a)

\begin{tabular}{|ll|l|l|l|l|l|}
\hline \multirow{2}{*}{} & \multicolumn{2}{|l|}{} & \multicolumn{2}{l|}{$\begin{array}{l}\text { Standardized } \\
\text { Coefficients }\end{array}$} & \\
\cline { 3 - 7 } Model & Unstandardized Coefficients & S & & Sig. \\
\hline \multirow{2}{*}{1} & (Constant) & 77.925 & 8.595 & & 9.066 & 0.000 \\
& AVEng & 3.035 & 2.512 & 0.176 & 1.208 & 0.232 \\
& Tenure & 1.060 & 0.808 & 0.191 & 1.312 & 0.196 \\
\hline
\end{tabular}

a. Dependent Variable: Analysis

Table 2(e): Linear Regression Model Summary of Total Exam Score and English Proficiency (AvEng) 


\begin{tabular}{|l|l|l|l|l|} 
Model & $\mathrm{R}$ & R Square & $\begin{array}{l}\text { Adjusted } \\
\text { Square }\end{array}$ & $\begin{array}{l}\text { Std. Error of the } \\
\text { Estimate }\end{array}$ \\
\hline 1 & $.413(\mathrm{a})$ & 0.171 & 0.138 & 12.32296975321350 \\
\hline
\end{tabular}

a. Predictors: (Constant), Tenure, AVEng

Coefficients(a)

\begin{tabular}{|c|c|c|c|c|c|c|}
\hline \multirow[b]{2}{*}{ Model } & & \multicolumn{2}{|c|}{ Unstandardized Coefficients } & \multirow{2}{*}{$\begin{array}{l}\text { Standardized } \\
\text { Coefficients } \\
\text { Beta }\end{array}$} & \multirow[b]{2}{*}{$\mathrm{t}$} & \multirow[b]{2}{*}{ Sig. } \\
\hline & & $\mathrm{B}$ & Std. Error & & & \\
\hline \multirow[t]{3}{*}{1} & (Constant) & 64.082 & 7.536 & & 8.503 & 0.000 \\
\hline & AVEng & 6.315 & 2.202 & 0.399 & 2.868 & 0.006 \\
\hline & Tenure & 0.162 & 0.708 & 0.032 & 0.228 & 0.820 \\
\hline
\end{tabular}

a. Dependent Variable: Total Exam 1 Score

Table3(a): Multivariate Tests(c)

\begin{tabular}{|c|c|c|c|c|c|c|}
\hline Effect & & Value & $\mathrm{F}$ & $\begin{array}{l}\text { Hypothesis } \\
\text { df }\end{array}$ & Error df & Sig. \\
\hline Intercept & Wilks' Lambda & 0.002 & 1110.144 & 4.000 & 10.000 & 0.000 \\
\hline AVEng & Wilks' Lambda & 0.001 & 2.232 & 92.000 & 42.079 & 0.002 \\
\hline Tenure & Wilks' Lambda & 0.019 & 3.170 & 24.000 & 36.096 & 0.001 \\
\hline AVEng * Tenure & Wilks' Lambda & 0.023 & 1.526 & 44.000 & 40.212 & 0.089 \\
\hline
\end{tabular}

Table 3(b): Tests of Between-Subjects Effects

\begin{tabular}{|ll|l|l|l|l|l|}
\hline Source & $\begin{array}{l}\text { Dependent } \\
\text { Variable }\end{array}$ & $\begin{array}{l}\text { Type III Sum of } \\
\text { Squares }\end{array}$ & df & $\begin{array}{l}\text { Mean } \\
\text { Square }\end{array}$ & F & Sig. \\
\hline $\begin{array}{l}\text { Corrected } \\
\text { Model }\end{array}$ & Know1 & 10876.029(a) & 40 & 271.901 & 2.293 & 0.054 \\
& Comp1 & $17497.171(\mathrm{~b})$ & 40 & 437.429 & 8.216 & 0.000 \\
& Appl1 & $21353.704(\mathrm{c})$ & 40 & 533.843 & 1.728 & 0.144 \\
& Analy1 & $9259.657(\mathrm{~d})$ & 40 & 231.491 & 1.615 & 0.176 \\
Intercept & Know1 & $127,210.429$ & 1 & $127,210.429$ & $1,072.693$ & 0.000 \\
& Comp1 & $148,527.893$ & 1 & $148,527.893$ & $2,789.741$ & 0.000 \\
& Appl1 & $92,168.841$ & 1 & $92,168.841$ & 298.306 & 0.000 \\
& Analy1 & $136,125.791$ & 1 & $136,125.791$ & 949.778 & 0.000
\end{tabular}

O'Neill, K. and Theuri, P. (2007). A Correlation Analysis of English Language Proficiency and Content-Area Cognitive Skills: A Gulf Region Perspective. Learning and Teaching in Higher Education: Gulf Perspectives 4(1) . http://www.zu.ac.ae/Ithe/Ithe04_01_03_oneill.htm 


\begin{tabular}{|c|c|c|c|c|c|c|}
\hline \multirow[t]{4}{*}{ AVEng } & Know1 & $8,166.697$ & 23 & 355.074 & 2.994 & 0.022 \\
\hline & Comp1 & $11,292.412$ & 23 & 490.974 & 9.222 & 0.000 \\
\hline & Appl1 & $11,280.006$ & 23 & 490.435 & 1.587 & 0.195 \\
\hline & Analy1 & $3,896.400$ & 23 & 169.409 & 1.182 & 0.387 \\
\hline \multirow[t]{4}{*}{ Tenure } & Know1 & $1,158.898$ & 6 & 193.150 & 1.629 & 0.216 \\
\hline & Comp1 & $3,398.424$ & 6 & 566.404 & 10.639 & 0.000 \\
\hline & Appl1 & $6,392.658$ & 6 & $1,065.443$ & 3.448 & 0.029 \\
\hline & Analy1 & $2,878.561$ & 6 & 479.760 & 3.347 & 0.032 \\
\hline \multirow{4}{*}{$\begin{array}{l}\text { AVEng } \\
\text { Tenure }\end{array}$} & * Know1 & $1,854.118$ & 11 & 168.556 & 1.421 & 0.270 \\
\hline & Comp1 & $3,064.378$ & 11 & 278.580 & 5.232 & 0.003 \\
\hline & Appl1 & $3,409.622$ & 11 & 309.966 & 1.003 & 0.491 \\
\hline & Analy1 & 951.396 & 11 & 86.491 & 0.603 & 0.796 \\
\hline \multirow[t]{4}{*}{ Error } & Know1 & $1,541.667$ & 13 & 118.590 & & \\
\hline & Comp1 & 692.130 & 13 & 53.241 & & \\
\hline & Appl1 & $4,016.667$ & 13 & 308.974 & & \\
\hline & Analy1 & $1,863.209$ & 13 & 143.324 & & \\
\hline
\end{tabular}
a. $\mathrm{R}$ Squared $=.876$ (Adjusted R Squared $=.494$ )
b. $\mathrm{R}$ Squared $=.962$ (Adjusted R Squared $=.845)$
c. $R$ Squared $=.842$ (Adjusted R Squared $=.355$ )
d. R Squared $=.832($ Adjusted R Squared $=.317)$ 